PESQUISA EXPERIMENTAL DAS CARACTERÍSTICAS DE
BRITADORES COM MECANISMO DE TRABALHO DE
MOVIMENTAÇÃO CICLOIDAL

\title{
EXPERIMENTAL RESEARCH OF CHARACTERISTICS OF CRUSHERS WITH CYCLOIDAL MOTION OF WORKING BODIES
}

\section{ЭКСПЕРИМЕНТАЛЬНЫЕ ИССЛЕДОВАНИЯ ХАРАКТЕРИСТИК ДРОБИЛКИ С ЦИКЛОИДАЛЬНЫМ ДВИЖЕНИЕМ РАБОЧИХ ОРГАНОВ}

\author{
RABAT, Ondabek Zh..$^{*} ;$ SALMANOVA, Alina N. ${ }^{2}$ \\ ${ }^{1}$ L.B. Goncharov Kazakh Automobile Road Academy (Kazadi), Department of Transport Technique and \\ Transport Organization, \\ 415 B Tashkentskaya Str., zip code 050061, Almaty - Republic of Kazakhstan \\ (phone: +77273871422)
}

${ }^{3}$ Ekibastuz Engineering and Technical Institute named after the Academician K. Satpayev, Department of Transport, 54A Energetikov Str., zip code 141208, Ekibastuz - Republic of Kazakhstan

(phone: +77187333503)

${ }^{*}$ Corresponding author

e-mail: rabat747@mail.ru

Received 01 December 2017; received in revised form 09 February 2018; accepted 25 May 2018

\begin{abstract}
RESUMO
A utilização de diferentes trituradores para obter o tamanho necessário do material de pedra. Este trabalho apresenta estudos experimentais das características de um britador com um movimento complexo do mecanismo de trabalho. Os objetivos do estudo são, uma análise da peneira do produto obtido (brita) e a determinação da velocidade ótima dos mecanismos de trabalho (rolos) para obter pedra britada cubificada de alta qualidade. No experimento, a matéria-prima é alimentada no espaço de trabalho (câmara de britagem) através do funil e se move por um fluxo plano entre os rolos. As bordas dos rolos rolam simetricamente de dois lados para o fluxo de material, aproximando-se na área da zona de britagem e divergindo na região da zona de descarga. Os autores determinaram os rolos ótimos para obter pedra britada cubificada de alta qualidade (acima de $80 \%$ ). Como resultado da pesquisa foi estabelecido que a composição dos grãos da fração está dentro do padrão da República do Cazaquistão 1225-2003 t.3 - obtém-se pedra britada cubiforme, com velocidade rotacional dos rolos de 100-120 rpm.
\end{abstract}

Palavras-chave: triturador, movimento cicloidal, brita, velocidade de rotação.

\section{ABSTRACT}

The use of different crushers to obtain the required size of the stone material. This work presents experimental studies of the characteristics of a crusher with a complex movement of working organs. The objectives of the study are, a sieve analysis of the obtained product (crushed stone) and the determination of the optimal speed of the working bodies (rolls) to obtain high-quality cubic shape crushed stone. In the experiment, the raw material is fed into the working space (into the crushing chamber) through the hopper and moves by a flat flow between the rollers. The edges of the rolls roll symmetrically from two sides to the flow of material, approaching in the area of the crushing zone and diverging in the region of the unloading zone. The authors determined the optimal rolls for obtaining high-quality cubiform crushed stone (over $80 \%$ ). As a result, of the research, it was established that the grain composition of the fraction is within the standard of the Republic of Kazakhstan 1225-2003 t.3 - is obtained cubiform crushed stone, with an rotational speed of rolls of 100-120 rpm.

Keywords: crusher, cycloidal motion, crushed stone, rotational speed. 


\section{АННОТАЦИЯ}

Для получения необходимого размера каменного материала используют различные дробилки. В работе приведены экспериментальные исследования характеристик дробилки со сложным движением рабочих органов. Задачами исследования являются ситовой анализ полученного продукта (щебня) и определение оптимальных оборотов рабочих органов (валков) для получения качественного кубовидного щебня. При эксперименте исходный материал подается в рабочее пространство (в камеру дробления) через загрузочную воронку и движется плоским потоком между валками. Грани валков накатываются симметрично с двух сторон на поток материала, сближаясь в области зоны дробления и расходясь в области зоны разгрузки. Авторами были определены оптимальные обороты валков для получения качественного кубовидного щебня (свыше 80\%). В результате исследований установлено, что зерновой состав фракции находится в пределах СТ РК 1225-2003 т.3 - получается кубовидный щебень, при оптимальной числе, оборота валков 100-120 об/мин.

Ключевые слова: дробилка, циклоидальное движение, щебень, скорость вращения.

\section{INTRODUCTION}

In the literature on kinematics and the design of the mechanism, three problems are defined for which coupling mechanisms are usually developed and used, namely: generation of functions, generation of motion, which is also known as solid guidance and path generation (Erdman and Sandor, 1991; Norton, 1992; Shigley and Uicker, 1980). Back in 1955, Freudenshtein, widely regarded as the father of modern kinematics of mechanisms and machines, presented an analytical method for designing the four barriers planar mechanism for generating functions (Freudenstein, 1955). Wang et al. presented a research on the synthesis of the mechanisms of planar coupling for the control of a solid (Wang et al., 2002). An interesting design and application of a flat four barrier mechanism for path generation were reported by Sung and $\mathrm{Wu}$ (Soong and $\mathrm{Wu}, 2009$ ). In general, the use of coupling mechanisms is associated with the transfer and transformation of motions and forces. In practical applications, communication mechanisms are more widely developed and used to transmit and transform movements, rather than forces. In such cases, the transferred forces are rather small (Guerrini et al., 2016; Guerrini et al., 2015; Nagy et al., 2013).

The jaw crusher is an example of the use of a plane coupling that is designed and used for transfer and transforms movements, but also must transmit, transform and apply the large forces necessary to crush hard rocks by compression. It is therefore important to understand the transmission characteristics of the jaw crusher mechanism and use them for the sound mechanical design of the crusher (Wang et al., 2018; Costa et al., 2018).

Today, the most commonly used types of jaw crushers are single switches and double switches. The original double jaw crusher was developed by Eli Whitney Blake in the US in 1857. The movement of the swinging jaw in the double bucket-crusher is such that it applies almost exclusively the compressive force to the crushed material (Meidanshahi, 2017; Segura-Salazar, 2017). This minimizes wear on the crushing surfaces of the jaws and makes a double slot crusher suitable for crushing highly abrasive and very hard materials. Even today, Blake's design with some minor improvements can still be found in mines and quarries around the world.

A single design, developed between the 1920s and 1950s, is a lighter crusher. Its swinging jaw has a movable elliptical motion so that it applies compression, as well as frictional force on the crushed material. This has a force effect that improves the capacity of the device, but it also leads to rapid wear of the crushing surfaces of the jaws. However, one jaw crusher with a switch has a lower set value than a double switch. Improvements in materials and design have made a single slit crusher more common today as a primary crusher in quarries (The Institute of...). According to Carter Russell, sales of a single jaw crusher exceeded the performance of a double-shift crusher by a factor of nine in the year of 1999.

Over time, several authors turned to a static force analysis of the mechanism of the double jaw crusher. Among the early such efforts is the study by Ham et al. (Ham et al., 1959)who 
performed a static analysis of the force of the double jaw crusher mechanism to determine the turnaround time required to overcome the known crushing resistance of the crushed material. They used a graphical method for analysis.

In the discussion of connections, Martin (Martin, 1982) showed the mechanism of a double jaw crusher switching as an example of a machine that uses a switching effect to obtain a large output force that acts a short distance, but it did not perform a static force analysis mechanism.

More generally, Lin and Chang (Lin and Chang, 2002) considered the issue of force transmissibility in the mechanisms of plane coupling. They obtained and proposed a Force Transmission Index $(\mathrm{FTI})$, which considered the power flow path from the input connection to the output connection. They calculated the effective force ratio (EFR) as the ratio of the sum of the actual power transmitted in each of the connecting connections in the power flow path to the sum of the maximum possible power that can be transmitted along the same power flow path. Then they obtained the FTI as the product of EFR and the mechanical advantage of the mechanism, thereby taking into account the effect of the external load acting on the mechanism. They compared their results with other force transmissibility indicators, such as the Jacobi matrix method (Denavit et al., 1965) and the joint force index (JFI) (Holte and Chase, 1994), and found that their FTI is more accurate. In addition, the Jacobi matrix method does not take into account the effect of the external load, whereas JFI does not consider the path of power flow in the mechanism.

The method used by Lin and Chang (Lin and Chang, 2002)includes an analysis of the static force and the determination of velocities at the joints in the power flow path.

This article presents a static and experimental analysis of the strength of the oneway grinder mechanism with the cycloidal movement of working mechanisms. As a result of this analysis, the characteristic force transfer ratio is obtained, which can be regarded as a mechanical advantage of the mechanism. This ratio can be used as a criterion for comparing different mechanisms of the crusher mechanism in order to select the most suitable design for use in this application.

\section{MATERIALS AND METHODS}

Theoretical formulas for determining the parameters of a crusher with a cycloidal motion of the working organs give only an approximate representation of them. To obtain more accurate data and to verify the calculated data, it is necessary to use the results of experimental studies of the technological parameters of the crusher (Erdman and Sandor, 1991; Norton, 1992).

Figure 1 shows a diagram of the design of an experimental crusher with cycloidal movement of working bodies (rolls), in Figure 2 the general view of the crusher, and in Figure 3 a photograph of the crusher.

The experimental crusher has the following technical characteristics:

1. Working elements - two rolls of square shape in cross-section:

- width, $\mathrm{mm}-280$

- height, $\mathrm{mm}-280$

- length, mm - 585

$\mathrm{mm}-45$

2. Maximum size of the starting material,

3. Ultimate strength of the starting material under compression, MPanot more than- 160

4. Limits of adjustment of the output slit, $\mathrm{mm}-6 \div 20$

5. Frequency of rotation of rolls, rpm -135 $6,5(10)$

6. Capacity, $\mathrm{m}^{3} / \mathrm{h}(\mathrm{t} / \mathrm{h})$ not less than -

7. Drive: twoelectricmotorsADM90L4UZ

- installed electric motor power, kW $2 \times 2,2$

- rotational speed, rpm - 1400

- V-belt drive:

gear ratio $-2,6$

- planetary gear:

gear ratio from shaft to planet -4

8. Overall dimensions, MM

- length -1030

- width -620

- height -750

9. Weight, $\mathrm{kg}-390$

The experimental crusher (Figure 1) consists of a frame 1 and two identical blocks 2, each of which contains a tetrahedral roll formed by crushing plates 3 fixed to a hub 4 and a drive comprising an electric motor 5 and a V-belt transmission 6 . The rollers are rotatably mounted on eccentrics drives of drive eccentric shafts 8 . 
The shafts are kinematically connected to each other by gear wheels 9 , which ensure their reciprocal synchronous rotation. The kinematic connection of each of the rolls with the drive contains planetary gears, the crown wheels 10 of which, with internal teeth, are fixedly fixed to the body of the block 2, and the satellites 11 are rigidly and coaxially connected to the hub 4 of the roll (Erdman and Sandor, 1991).

The drive was carried out in the form of a shaft eccentric 7 integrals with the shaft 8 . To balance the centrifugal forces of inertia of the rotating masses of the rollers, the shafts 8 are equipped with counterweights 12. Each of the blocks 2 is mounted on the frame 1 on hinges with the possibility of turning around their axes. The blocks are interconnected through an elastic element (spring) and equipped with stops. Gear from the carrier to the satellite $\mathrm{i}_{n}=\omega_{\mathrm{H}} / \omega_{\mathrm{c}}=4$. Where, $\omega_{\mathrm{H}}$ - the angular velocity of the carrier (shaft); the angular velocity of the satellite.

The outer contour of the cross-section 16 of each of the rolls is a square with convex sides, coinciding with the inner envelope of the family of epitrochoid, described by points belonging to the trajectory of motion of all the vertices of this square(Norton, 1992).

The trajectory of the motion of all vertices of a square is the same flat curve-the hypotrochoid17 in the form of a pentagon (Figure 1 ). The radius of curvature and, consequently, the gripping capacity of the working surfaces of tetrahedral rollers is the same as for conventional cylindrical rolls with a diameter D. Moreover, the overall dimensions of the cross-section of a square roll are approximately half that of the diameter of a cylindrical roll (Ofodile and Turnera, 2017).

\section{RESULTS AND DISCUSSION:}

The crusher works as follows. When the drive shafts 8 rotate, the satellites 11 , rolling inside the crown wheels 10 , make a planetary motion - a rotational movement around two parallel axes. Together with the satellites 11, the planetary movement also makes rigidly connected rolls, rotating towards each other. With this motion, the edges of tetrahedral rolls describe the surfaces in the form of regular pentagonal prisms, and the faces of the rolls (working surfaces) roll over these surfaces as along the guides with some slip.
The raw material is fed into the working space (into the crushing chamber) through the hopper and moves by a flat flow between the rollers. The edges of the rolls roll symmetrically from two sides to the flow of material, approaching in the area of the crushing zone and diverging in the region of the unloading zone. When approaching the edges of the rolls, they affect the pieces of crushing material and crush them. The position of the crushing chamber and the discharge gap varies cyclically, moving vertically. And the value of the minimum gap between the rollers (width of the discharge gap) remains constant. When the edges of the rolls are approaching in the working space to the extent of the minimum clearance, the crushing cycle stops. Further, the edges of the shafts move vertically downward and then diverge in opposite directions. At this time, the next pair of working faces of the rolls converge in the crushing zone and the crushing cycle is repeated. Four cycles of crushing occur in one roll revolution.

Upon entering the crushing chamber of the non-rubble objects, for example, metallic, there are significant reactive forces acting on the rolls, and through them and on the blocks 2. As a result of these forces on each of the blocks, a moment is created relative to the hinge axis, tending to turn the block in the direction opposite to the direction of rotation of the roll. When the magnitude of this moment becomes greater than the magnitude of the resulting torque from the gravity of the block and the force of the spring relative to the same hinge axis, the blocks will rotate by some angle. In this case, the width of the unloading slot will increase and the unbreakable object will pass between the rollers, i. e. through the discharge gap.

The width of the discharge gap is regulated by tightening or releasing the springs of the shock absorbers by means of a nut. In this case, the blocks rotate about the axis of the hinges at some angle and thereby the adjustment of the discharge gap is achieved.

The experimental crusher was installed on the foundation blocks in the laboratory building of Kazakh Road Academy. In the beginning, the crusher was tested, after being connected to the power grid, on the canvas without the supply of stone material.

The grain composition of the material at the inlet of the crusher and at the outlet after crushing is determined by means of a sieve 
analysis.

The stone material for crushing (with a certain strength $\sigma_{c z h}=80 / 160 M P a$ ) was removed after the screening of the grains was less than 45 $\mathrm{mm}$ and through the tray was fed into the receiving funnel of the experimental crusher.

Consumption of stone material was set by adjusting the feed material to the measurement of the weight of the party. The material after crushing (crushed stone) on an experimental crusher was collected in a measuring box, while the crusher's working time was fixed with a stopwatch.

The frequency of rotation of the working elements was synchronized with the help of a "variable speed drive" - the regulator of the engine speed (INVERTER - frequency converter $7.5 \mathrm{~kW}$ ), and checked by a tachometer.

Figures 4-7 present in a tabular and graphical form the ratio of grains of different sizes (fractions) that make up the crushed stone and expressed in percentage relative to the weight of the test sample. From the analysis of the experimental results, it follows that the grain composition of the fractions that make up the crushed stone is within the recommended limits (ST RK 1225-2003 t.3).

Figure 8 shows the dependence of the grain composition of fractions on the number of revolutions of the rolls with an output gap of 15 $\mathrm{mm}$. The optimal speed of rolls lies in the range of $100-120 \mathrm{rpm}$. Then the output of the crushed stone of fractions of $15 \mathrm{~mm}$ is more than $80 \%$ and is approximated by the equation $Y=0,005 x^{2}$ $+1,215 x+7,196$.

Thus, the efficiency of the experimental crusher was tested. It is established that the product corresponds to the passport data and technical documentation.

Sieve analysis of the obtained product (crushed stone) made it possible to establish that the grain composition of the fractions is within the limits of ST RK 1225-2003 t.3.

As a result, of experimental studies, optimal roll speeds have been determined to produce high-quality cubiform crushed stone (over 80\%) (Table 1 - Table 4).

\section{CONCLUSIONS:}

This article presents experimental studies of the characteristics of a crusher with the cycloidal movement of the working organs. The authors used crushers during the experiments. The grain composition of the material is determined by means of a sieve analysis.

1. Experiments have confirmed that the crusher with the cycloidal movement of the working elements and the principle of action, which is the basis of the construction, is operable. The crusher provides a qualitative (cubiform) crushed stone.

2. Sieve analysis of the obtained product (crushed stone) made it possible to establish that the grain composition of fractions is within the limits of ST RK 1225-2003 t.3.

3. The optimum number of revolutions of rolls lies in the range of $100-120$ rpm.

\section{REFERENCES:}

1. Costa, A. G., Maldonado, J. L. B., Romero, F. A., Sanmartín, J. C., Valarezo, M., Castillo H. N4SID method applied to obtain a discretetime linear state space system as a mathematical model of a jaw crusher prototype, 2018, Available at: https://ieeexplore.ieee.org/document/8229620 I

2. Denavit, J., Hartenberg, R. S., Razi, R., Uicker, J. J. Journal of Applied Mechanics, 1965, 32 (4), 903-910.

3. Erdman, A. G., Sandor, G. N. Mechanism Design: Analysis and Synthesis, London: Prentice-Hall, 1991.

4. Freudenstein, F. Transactions of the ASME, 1955, 77, 853-861.

5. Guerrini, L., Masella, P., Migliorini, M., Cherubini, C., Parenti, A., J. Food Eng., 2015, 157, 84-87.

6. Guerrini, L., Migliorini, M., Giusti, M., Parenti, A. Advanced Science, 2016, 119 (1), 1600156

7. Ham, C. W., Crane, E. J., Rogers, W. L. Mechanics of Machinery, New York: McGrawHill Book Company, 4th edition, 1958.

8. Holte, J. E., Chase, T. R., A force transmission index for planar linkage mechanisms, in Proceedings of the ASME Mechanisms Conference, 1994, 377-386.

9. Lin, C. C., Chang, W. T. Mechanism and Machine Theory, 2002, 37 (12), 1465-1485,

10. Martin, G. H. Kinematics and Dynamics of Machines,New York: McGraw-Hill, 1982. 
11. Meidanshahi, V. Computer and Chemical Engineering, 2017, 103, 39-57.

12. Nagy, Z., Thomas, D. L., Weiskopf, N. Advanced Science, 2013, 71(2), 506-515.

13. Norton, R. L., Design of Machinery: An Introduction to the Synthesis and Analysis of Mechanisms and Machines, New York: McGraw-Hill, 1992.

14. Ofodile N. A., Turnera M.C. European Journal of Control, 2017, 28, 22-31.

15. Segura-Salazar, J. Minerals Engineering, 2017, 111, 222-228.

16. Shigley ,J. E., Uicker, J. J. Theory of Machines and Mechanisms, New York: McGraw-Hill Book Company, 1980.

17. Soong, R. C., Wu, S. L. Journal of the Chinese Society of Mechanical Engineers, 2009, 30 (3), 249-257.

18. The Institute of Quarrying Australia, Technical Briefing Paper No. 6. Available at: https://www.quarry.com.au/files/technical_pap ers/microsoft_word_-_technical_paperno.6.doc.pdf.

19. Wang, S., Guo, J.; Xu, D. Non-Contact LowPower Proximity Switch Based on Kitchen Garbage Crusher. International Conference on Intelligent Transportation, Big Data \& Smart City, 2018, 101-104.

20. Wang, Z., Yu, H., Tang, D., Li, J. Mechanism and Machine Theory, 2002, 37(7), 673-684. 

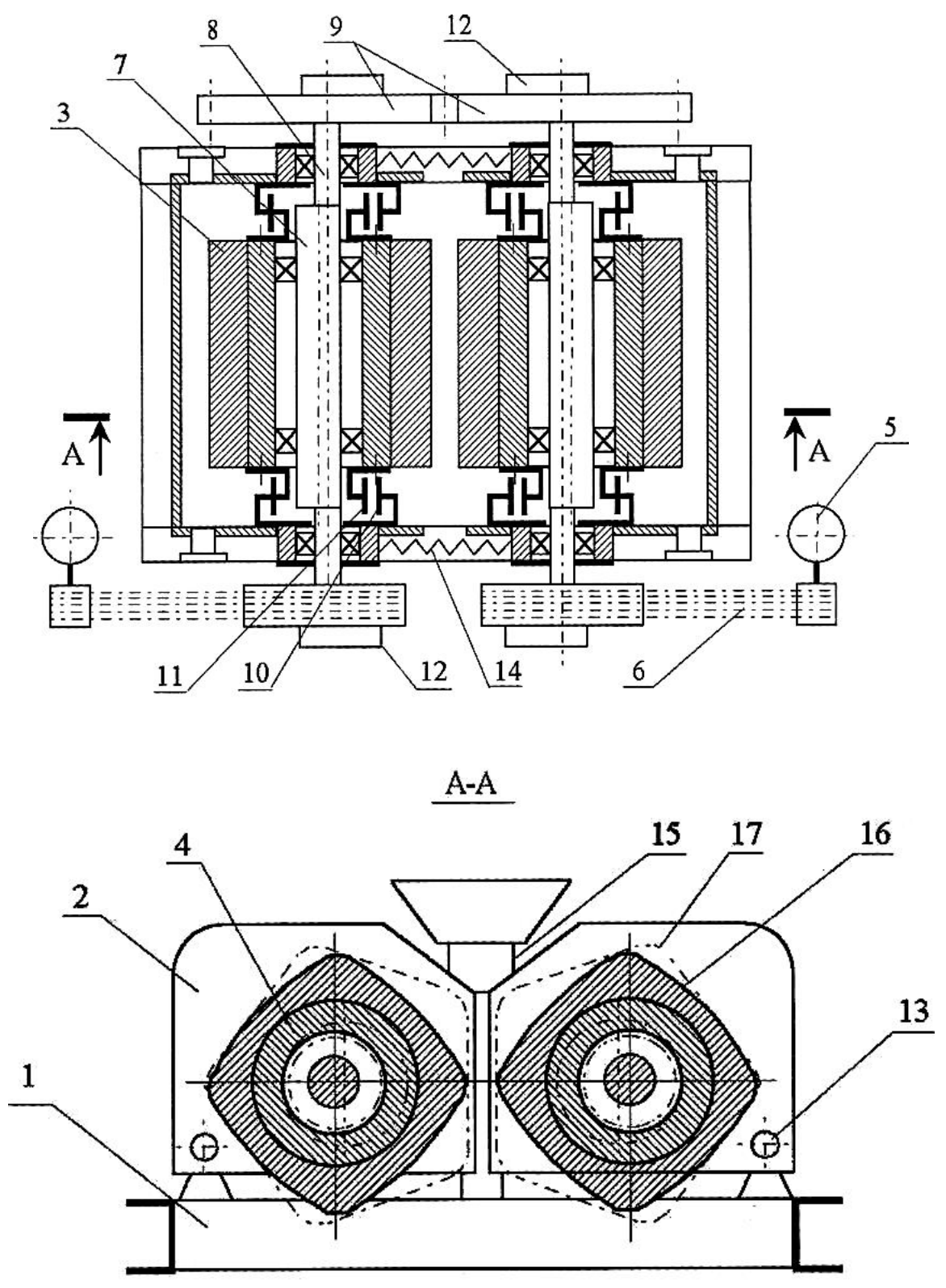

Figure 1. Schematic structure of the crusher (1 - frame; 2 - block; 3 - crushing plate; 4 the hub; 5 - the electric motor; 6 - V-belt transmission; 7 - carrier; 8 - drive eccentric shaft; 9 - cogwheels; 10 - the crown wheel of a planetary gearbox; 11 - satellite; 12 counterweights; 13 - the hinge; 14 - a spring; 15 - the emphasis; 16 - polygon (crosssection of the roll); 17 - the hypotrochoid) 

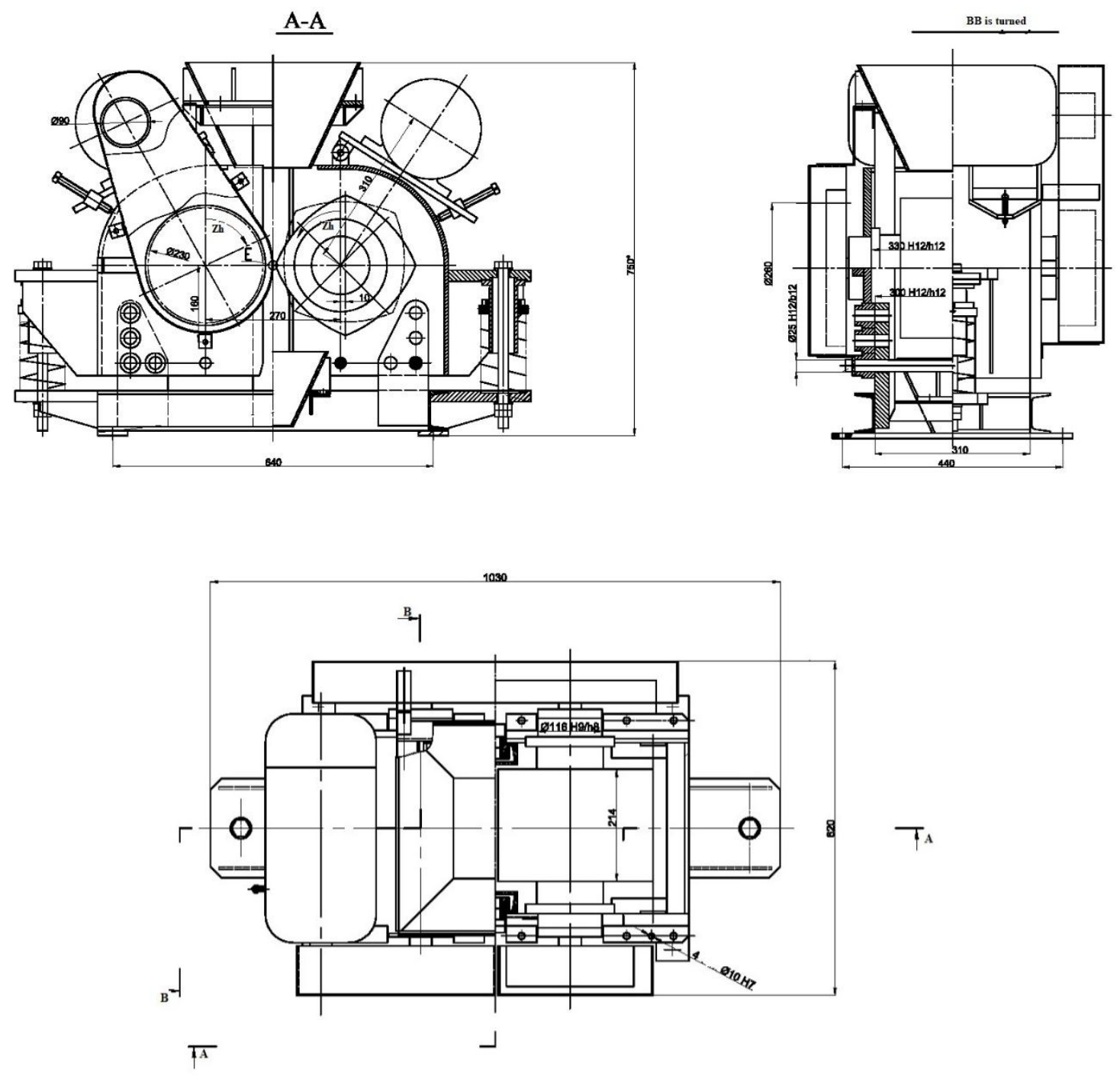

Figure 2. General view of the crusher

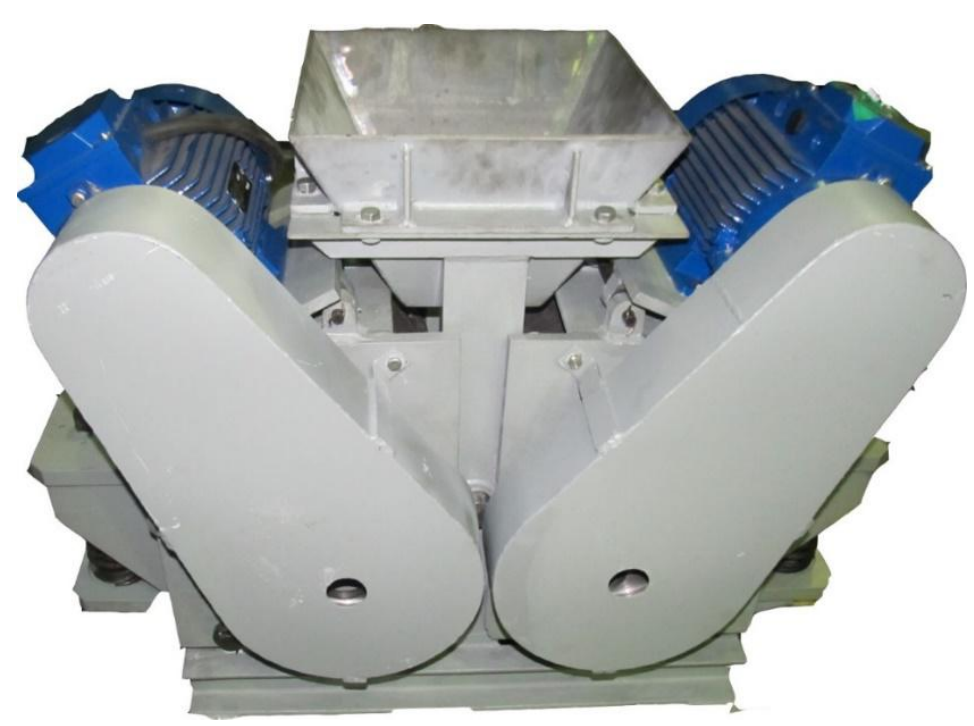

Figure 3. Photo of the crusher 


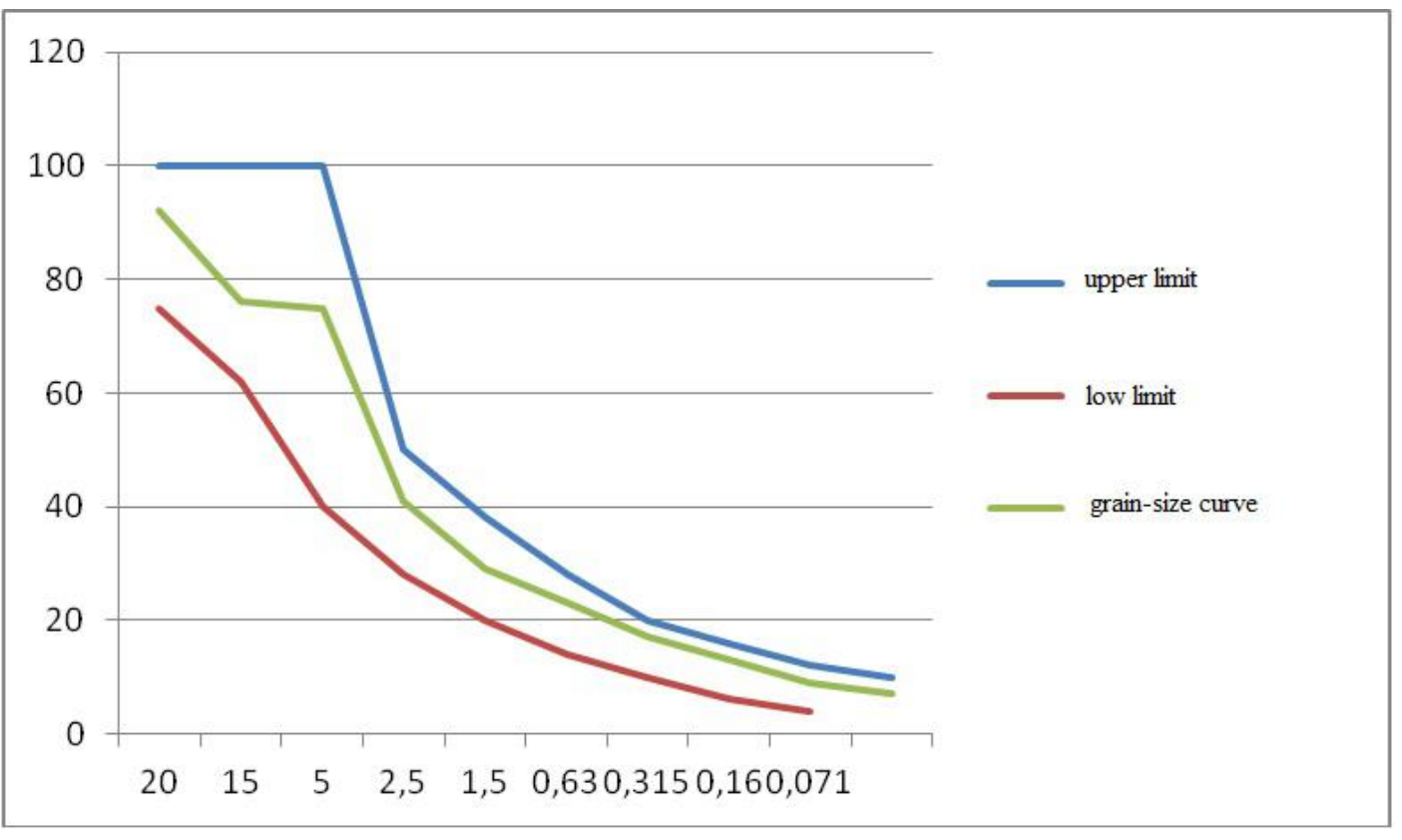

Figure 4. Determination of the grain (granulometric) composition of the fractions that make up the crushed stone

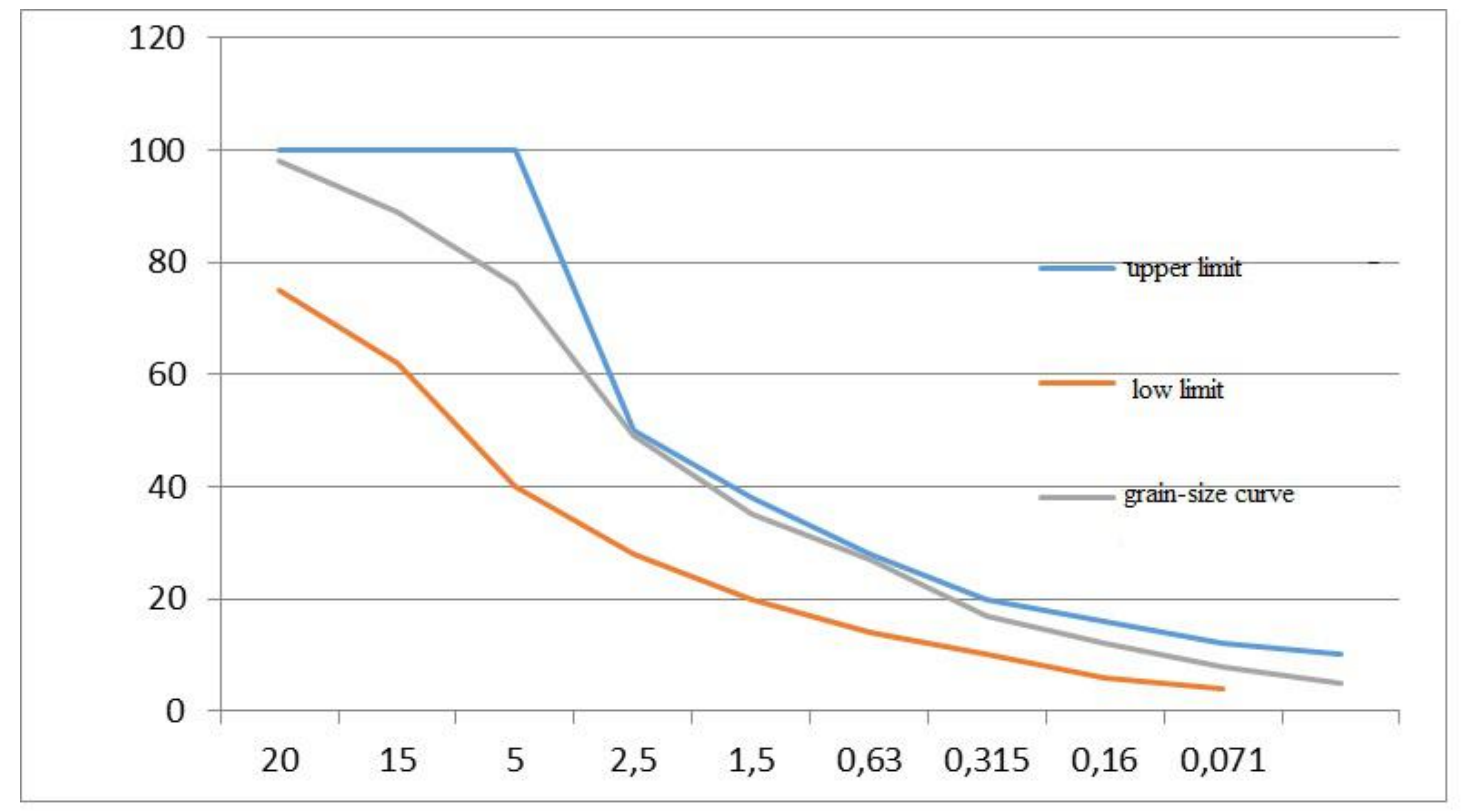

Figure 5. Determination of the grain (granulometric) composition of the fractions that make up the crushed stone 


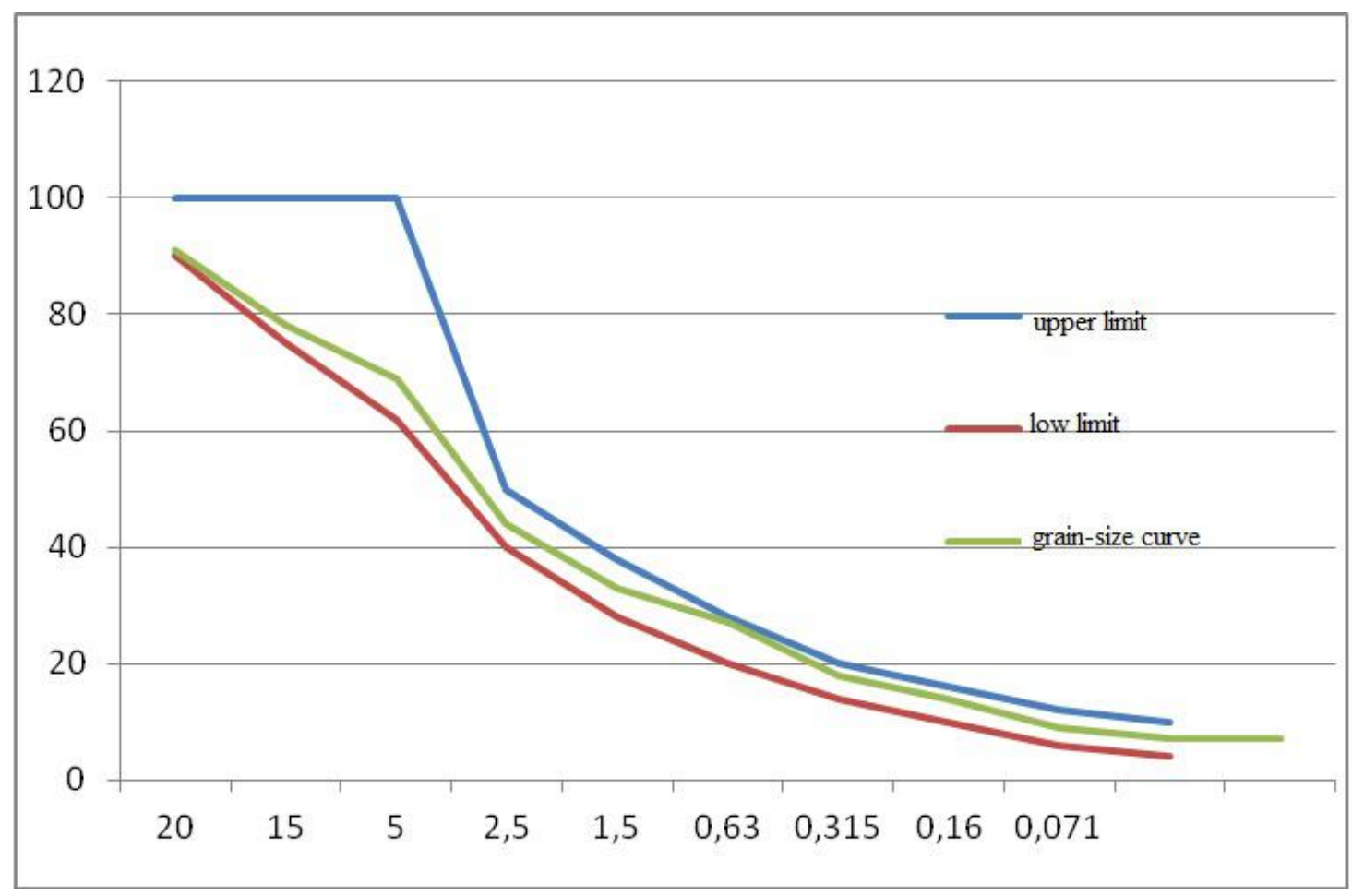

Figure 6. Determination of the grain (granulometric) composition of the fractions that make up the crushed stone

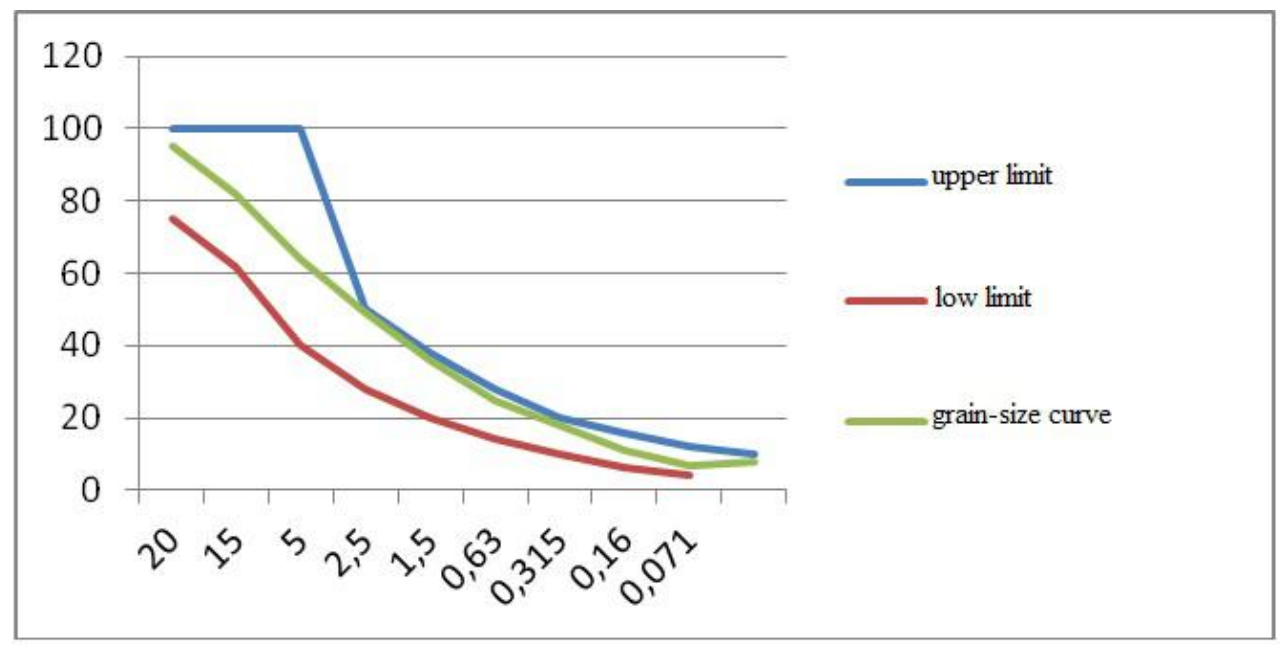

Figure 7. Determination of the grain (granulometric) composition of the fractions that make up the crushed stone 


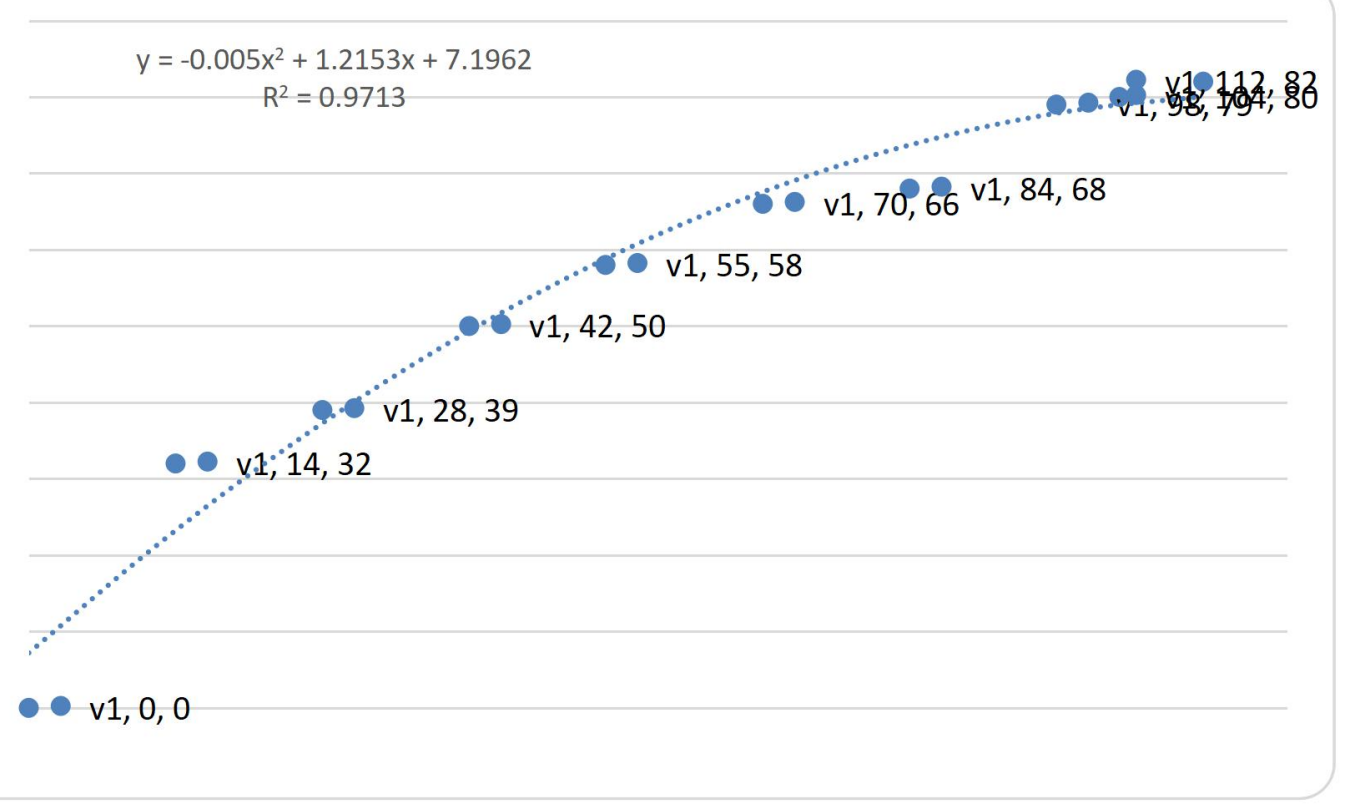

Figure 8. Dependence of the grain composition of fractions on the number of revolutions of rolls 
Table 1. Experimental studies of the stone cobblestone of the Aksai quarry, with a mass-2007,77gram

\begin{tabular}{|c|c|c|c|c|c|c|c|c|c|c|c|}
\hline \multicolumn{12}{|c|}{$\begin{array}{l}\text { Description: Stone material No. } 1 \\
\text { m-2007,77 year }\end{array}$} \\
\hline Name of & & & & & Sieve & size, $n$ & & & & & \\
\hline residues & 20 & 15 & 10 & 5 & 2.5 & 1.25 & 0.63 & 0.315 & 0.16 & $\begin{array}{l}0.07 \\
1\end{array}$ & $<0 / 071$ \\
\hline $\begin{array}{l}\text { Private } \\
\text { residues gr }\end{array}$ & 526,63 & 872,62 & 148,89 & 291,5 & 90,91 & 18,42 & 29,39 & 18,57 & 6,63 & 2,21 & 2 \\
\hline $\begin{array}{l}\text { Private } \\
\text { residues } \%\end{array}$ & 26,23 & 43,46 & 7,42 & 14,52 & 4,53 & 0,92 & 1,46 & 0,92 & 0,33 & 0,11 & 0,09 \\
\hline $\begin{array}{l}\text { Full } \\
\text { residues\% }\end{array}$ & 26,23 & 69,69 & 77,11 & 91,63 & 96,16 & 97,08 & 98,54 & 99,46 & $\begin{array}{l}99,7 \\
9\end{array}$ & $\begin{array}{l}99,9 \\
1\end{array}$ & 100 \\
\hline Full costs & 91,04 & 78,45 & 69,93 & 44,59 & 33,28 & 27,61 & 18,26 & 14,02 & 9,35 & 7,06 & 7,83 \\
\hline $\begin{array}{l}\text { Limits (ST } \\
\text { RK 1225- } \\
2003 \text { t3) }\end{array}$ & $90-100$ & $75-100$ & $62-100$ & $40-50$ & $28-38$ & $20-28$ & $14-20$ & $10-16$ & $6-12$ & $4-10$ & \\
\hline
\end{tabular}

Table 2. Experimental researches of rock cobs, mass-1922.39 grams

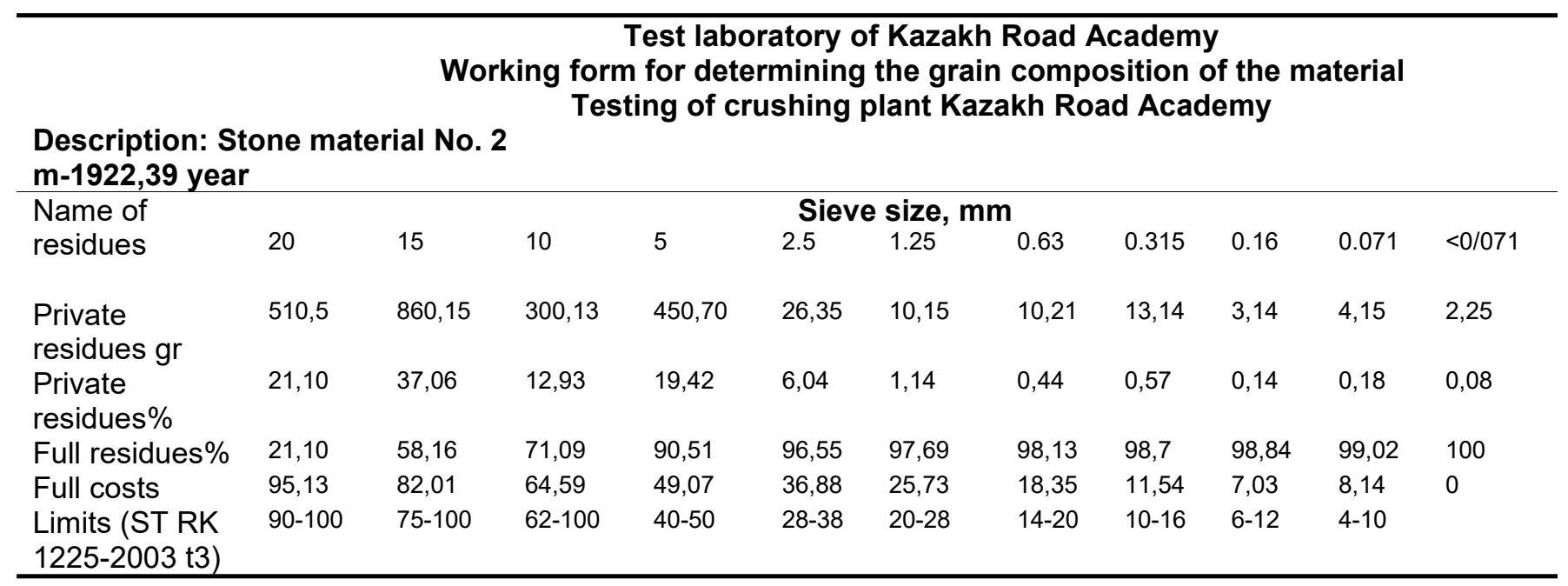


Table 3. Experimental studies of stone cobblestone quarry of the Karatau foothills, with a mass-2296.26gram

\begin{tabular}{|c|c|c|c|c|c|c|c|c|c|c|c|}
\hline \multicolumn{12}{|c|}{$\begin{array}{l}\text { Description: Stone material No } 3 \\
\text { m-2296,26year }\end{array}$} \\
\hline Name of & & & & & Sie & ve siz & $\mathrm{mm}$ & & & & \\
\hline residues & 20 & 15 & 10 & 5 & 2.5 & 1.25 & 0.63 & 0.315 & 0.16 & 0.071 & $<0 / 071$ \\
\hline $\begin{array}{l}\text { Private } \\
\text { residues gr }\end{array}$ & 610,5 & 950,6 & 20,15 & 340,7 & 100,6 & 20,27 & 35,6 & 22,1 & 8,33 & 5,31 & 2,13 \\
\hline $\begin{array}{l}\text { Private } \\
\text { residues } \%\end{array}$ & 26,59 & 41,4 & 8,72 & 14,84 & 4,38 & 0,88 & 1,55 & 0,96 & 0,31 & 0,23 & 0,14 \\
\hline $\begin{array}{l}\text { Full } \\
\text { residues } \%\end{array}$ & 26,59 & 67,99 & 76,71 & 91,55 & 95,93 & 96,81 & 98,36 & 99,32 & 99,63 & 99,86 & 100 \\
\hline Full costs & 98,21 & 89,14 & 76,36 & 49,54 & 35,76 & 27,12 & 17,82 & 12,33 & 8,56 & 5,44 & 0 \\
\hline $\begin{array}{l}\text { Limits (ST } \\
\text { RK 1225- } \\
2003 \text { t3) }\end{array}$ & $\begin{array}{l}90- \\
100\end{array}$ & $\begin{array}{l}75- \\
100\end{array}$ & $\begin{array}{l}62- \\
100\end{array}$ & $\begin{array}{l}40- \\
50\end{array}$ & $\begin{array}{l}28- \\
38\end{array}$ & $\begin{array}{l}20- \\
28\end{array}$ & $\begin{array}{l}14- \\
20\end{array}$ & $10-16$ & $6-12$ & $4-10$ & \\
\hline
\end{tabular}

Table 4. Experimental research waste production- construction brick, concrete pieces, limestone materials with a mass-1627,59 gram

\begin{tabular}{|c|c|c|c|c|c|c|c|c|c|c|c|}
\hline \multicolumn{12}{|c|}{$\begin{array}{l}\text { Description: Stone material № } 4 \\
\text { m-1922,39 year }\end{array}$} \\
\hline Name of & & & & & Siev & size, & $\mathrm{im}$ & & & & \\
\hline residues & 20 & 15 & 10 & 5 & 2.5 & 1.25 & 0.63 & 0.315 & 0.16 & 0.071 & $<0 / 071$ \\
\hline $\begin{array}{l}\text { Private } \\
\text { residues } \\
\text { gr }\end{array}$ & 407,1 & 815,65 & 211,45 & 347,58 & 103,16 & 16,45 & 7,35 & 9,21 & 1,86 & 1,45 & 1,13 \\
\hline $\begin{array}{l}\text { Private } \\
\text { residues \% }\end{array}$ & 21,18 & 42,43 & 10,10 & 18,08 & 5,37 & 0,85 & 0,38 & 0,48 & 0,09 & 0,08 & 0,06 \\
\hline $\begin{array}{l}\text { Full } \\
\text { residues } \%\end{array}$ & 21,18 & 63,61 & 73,71 & 91,79 & 97,16 & 98,01 & 98,39 & 98,87 & 98,96 & 99,05 & 100 \\
\hline Full costs & 92,03 & 76,44 & 75,29 & 41,47 & 29,96 & 23,01 & 17,83 & 13,67 & 9,09 & 7,16 & 0 \\
\hline $\begin{array}{l}\text { Limits (ST } \\
\text { RK 1225- } \\
2003 t^{3} \text { ) }\end{array}$ & $90-100$ & $75-100$ & $62-100$ & $40-50$ & $28-38$ & $20-28$ & $14-20$ & $10-16$ & $6-12$ & $4-10$ & \\
\hline
\end{tabular}

PERIÓDICO TCHÊ QUÍMICA•www.periodico.tchequimica.com• Vol. 15 N. 30.

• ISSN 1806-0374 (impresso) • ISSN 1806-9827 (CD-ROM) • ISSN 2179-0302 (meio eletrônico)

(C) 2018. Porto Alegre, RS. Brasil 